\title{
The experience of ethnological reconstruction of Nenets shamanistic ritual on the topic "prediction of the future"
}

The phenomenon of shaman and shamanism has drawn the attention of scientists of many specialties and common people alike for a long time. People who call themselves shamans appeared in post-communist Russia, particularly in large cities. One can make sure of it while leafing through Moscow-based advertising newspapers Extra-M and Center-plus. There has been an open positive interest in the phenomenon of shaman and shamanism of peoples, who have acquired centuries-long experience of performing shamanistic rituals, in Russia due to democratization of our society (see Vinokurova 1997).

Deplorably, the phenomenon of Nenets shamanism has not been sufficiently studied yet, although it has been documented from the 16th century (see e.g. Lar 1995; Lehtisalo 1924; Khomich 1981). In my report I consider a Nenets shamanistic ritual on the basis of its reconstruction. On July 18, 1997 Gennady T. Lapsui demonstrated the art of Nenets shamans whose rituals he had been witness of. I took pictures of his performance, while his daughter M. Anagurichi recorded it on video. On July 28 , Gennady Lapsui and I commented upon the shamanistic ritual, having broken it into several acts, as it were.

Dwellers of two, three and sometimes up to ten chums (tents of reindeer skins) can gather for a shamanistic ritual. The total number of dwellers of ten chums approximates from 40 to 50 . As a rule, a ritual lasts from 10 p.m. until 6 a.m. People do not have meals during the ritual. Each part equals to one ngedalawa (a stretch of sledge-riding without a pause, from 30 to 60 minutes). Let me remind you that this report deals with such a type of a shamanistic ritual in which there are two main characters: tadyebya, i.e. the shaman and teltanggoda (his assistant). Teltanggoda (the photos do not feature him) repeats tadyebya's actions.

Gennadiy Lapsui performs a shamanistic ritual on a drum he calls as syi' $i w$ li khengorota pyenzyer. The drum is called so after the name khengor, which refers to a resonator strut of the drum. A drum has 24 khengors, original drum bows between the outside part of the drum and the triune string (interwoven in the form of a plait) girdling those 24 khengors (usually translated as 'horns' or 'bumps'). The Nenets term khengor can be translated as belonging to the thunder, thunder or sounding like a thunder. Seven out of 20 khengors are made of bone, hence the name of the drum - 'a seven-horned drum sounding like a thunder' - while the rest 
17 khengors, which are made of wood, are minor.

We refrain from using the term "shaman's drum" deliberately inasmuch as I know at least three functional categories of Nenets drums (the code according to systematization of Mahillon and Sachs \& Hornbostel: 211.311.86):

1) a shaman's personal drum - his professional tool which is buried together with him;

2) a Nenets family drum which in some cases is given to a shaman for performing his ritual by another family from another clan;

3) a family drum which is used for salutatory hymns to nature and space.

The drum of the second type was used during reconstruction.

\section{Episode 1}

An important moment in a shamanistic ritual is the tuning of the instrument by heating it properly on fire (see Photo 1.). After the drum is heated, the shaman inspects it to make sure that the membrane is heated enough and taps on the drum.

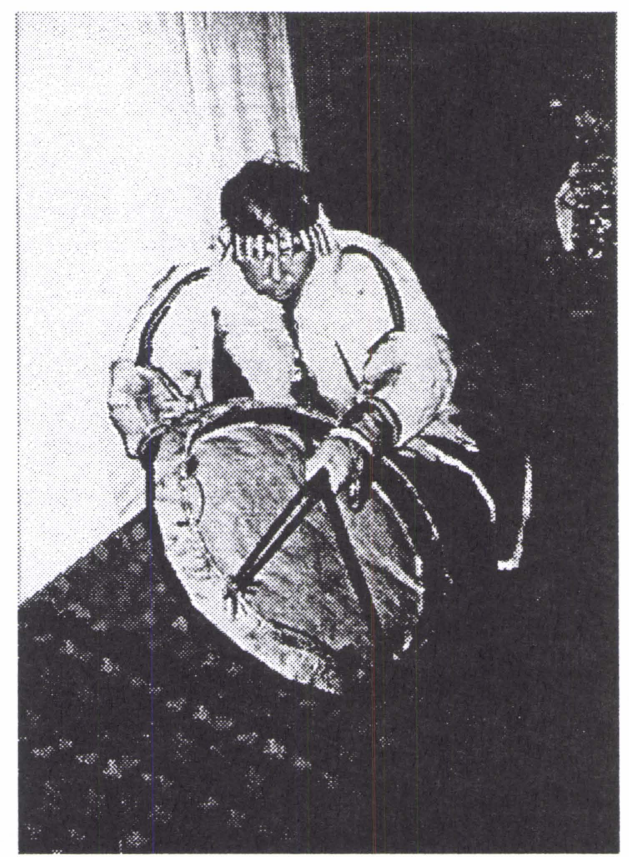

\section{Photo 1.}

\section{Episode 2}

Having heated one side of the drum over the fire, the shaman turns it over to the other side and heats again, tapping on it with a handle to make sure that it is in the 
needed state.

\section{Episode 3}

The shaman again passes the drum over the fire, puts it on the floor with its open part down to keep it heated; soon the drum begin to tikadali", as it were, from heat (tikadali" means to ring in Nenets, according to my rough translation) - this is the most significant moment. It signifies that the instrument is ready for being played. This moment is always poeticized in epic songs khinabts: the drum, which is lying on horizontal poles of the chum over the hearth, begins to kharta khinoli (sing by itself) shortly afterwards.

\section{Episode 4}

The shaman continues to inspect the drum, tapping on it for some time, standing on his feet.

\section{Episode 5}

After that he begins to tap on the drum with force, as well standing.

\section{Episode 6}

Then the shaman stops tapping on the drum, sits down and begins to tap on it with force, closes his eyes and begins to sing some time later. The following (Example 1.) is an extract from sambadabts (shamanistic song) performed by Valentina $\mathrm{N}$. Salinder. Her father Ngaptiko Lapsui used to sing it sometimes for illustration. An opportunity to record shamanistic songs outside the context of a ritual proper is a happy occasion for a researcher as their performance is strictly tabooed.

Original basic text: ${ }^{1} \quad$ Translation:

Salya Yawm' xawrasy, Along the Ob', downstream, syidntyet yaw' xabt, with eight coastal reindeer-bulls (running ahead), pyemdyaryido' xudsa. the nap-fur on their neck is swinging.

Salya Yawm' xawrasy, Along the Ob', downstream, syidntyet sew nyaty. the eight, with their beautiful eyes.

xadoty mara' xarw', The larches of their pasture, coastal larches, xonabtyange tabyedawi. by them, hanging as evening-meal. syidntyet sew nyaty, The eight, with their beautiful eyes, syidntyet yaw' xabt, with eight coastal reindeer-bulls (running ahead), Salya Yawm' xawrasy, along the Ob', downstream, pyemdyaryido' xudsa. the nap-fur on their neck is swinging.

\footnotetext{
${ }^{1}$ Letter " $\mathrm{x}$ " in the transcriptions is equivalent with the letter combination "kh" in the rest of the text.
} 
$\delta=210 \quad$ "g1"=f\#1-g"
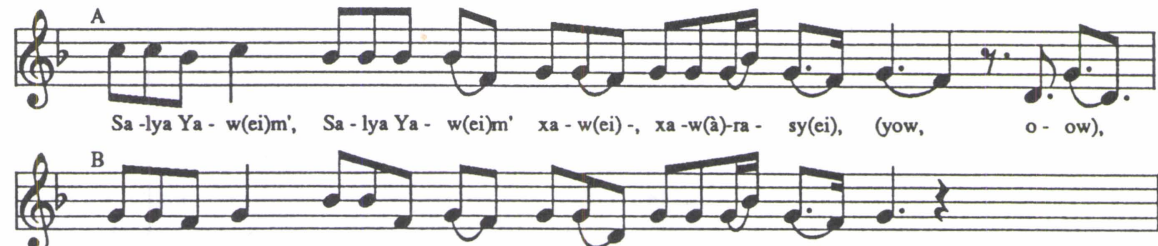

syi-d(a)n-tye - $t(e i), \quad$ syi-d(a) n-tye - $t(e i) \quad x a b-t(e i), \quad y a-w(e i n g)^{\prime} k a b-t(e i) \quad$ (yow),
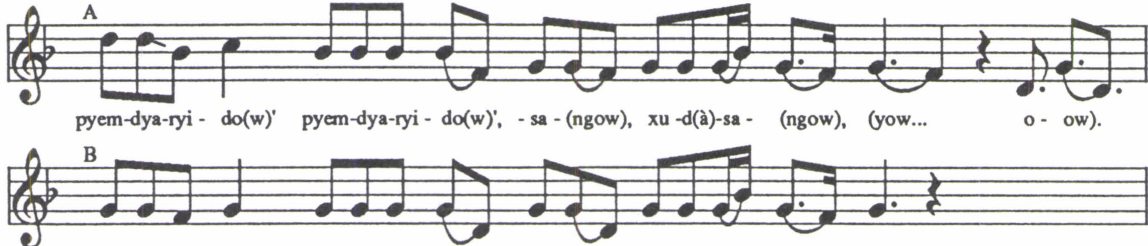

Sa -lya Ya-w(ei)m', Sa-lya Ya-w(ei)m', xa-w(ei)-, xa-w(a)-ra- sy(e)i, (yow),

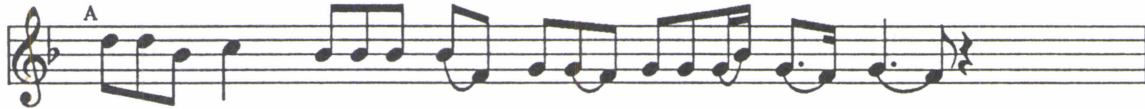

syi-d(a)n-tye - t(ei), syi-d(a) n-tye - $t(e i), \quad$ nya -ty(ei), [h]e-w(a) nya - ty(ei), (yow).
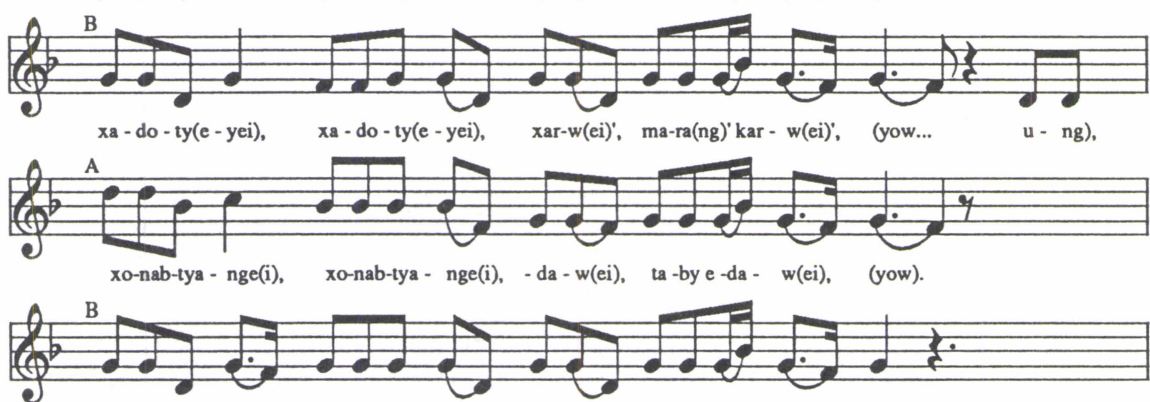

syi-d(a)n-tye - t(ei), syi-d(a)n-tye -t(ei), nya-ty(ei), [h]e-w(a) nya- ty(ei), (yow),
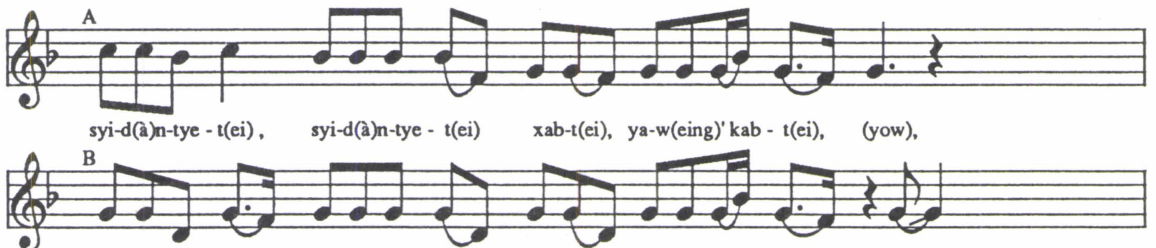

Sa -lya Ya - w(ei)m', Sa -lya Ya-w(ei)m', xa-w(ei)-, xa-w(a)-ra - sy(ei)... (yow),

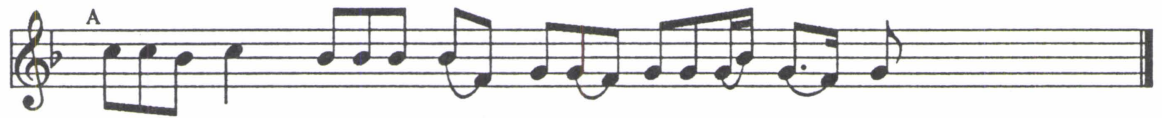

pyem-dya-ryi - do(w)', pyem-dya-ryi - do(w)', - sa - ngow, xu-d(a)-sa - (ngow), (yow).

Example 1. Sambadabts (Shamanistic song of Ngabtiko Lapsui). Performed by Valentina Ngabtikovna Salinder. Recorded by E. T. Pushkarëva, Nyda 1993. Transcription and translation (into Russian) of the text by E. T. Pushkarëva. Further transcription of the text, its translation into English and transcription of the singing by J. Niemi. 
At this moment taking part in the shamanistic ritual are: pyenzyerta khekhe (the drum deity), who is held as tadyebya pida syita letambadada (the shaman's guard), shaman himself as nyenzamyindya (the leading [? reindeer], deities' interpreter). They are joined by teltanggoda (the assistant) as pyelyeyda (the second [? reindeer], shaman's interpreter).

\section{Episode 7}

Having felt the force of the drum, the shaman begins to call his assistant spirits. He sends his messenger - the iron eagle (shaman Yadne Kylalo had such a messenger) - for them. The iron eagle notifies all the spirits dependent on the shaman: "We'll perform a shamanistic ritual tonight".

\section{Episode 8}

The shaman begins to sing, for one ngedalawa (for 30 to 60 minutes), and after that an iron eagle begins to scream on the end of the sacred syimzi pole (a pole in the center of the chum). The eagle notifies all heavenly spirits who are dependent on the shaman. After he notifies everyone, the spectators exclaim "Hear! Hear! Hear!" The shaman says to the woman who is keeping up the fire: "We must sanctify the dwelling, our heads became heavy". The woman sprinkles the fire with liquid fat seven times and throws sable suet into the fire (as incense).

\section{Episode 9}

In the next phase the shaman stands up, goes into ecstasy, passes round the fire seven times, sun-wise. The assistant repeats all the movements of the shaman. Among teltanggoda there are those who take the lead over the shaman, by joining the shaman as soon as the latter begins to sing. Then the shaman knocks on the assistant's forehead with his handle and declines his services, saying: "Give me another assistant! Who wants to be my assistant?" A good assistant must join the shaman when the latter finishes a sentence, and the shaman will in turn continue singing as soon as teltanggoda finishes his part.

\section{Episode 10}

Continuing the ritual, shaman sends the eagle to call earthly spirits, seven types of underground spirits. He again performs a ritual for a ngedalawa (for 30 to 60 minutes). The shaman says: "I notified everyone, pull up your legs, grandmother Yamyunya is coming". Now all the deities have come. The shaman has gathered heavenly and earthly deities, as well as all his settled deities and seven kinds of underground deities beyond seven permafrosts, every one of them. The spectators exclaim: "Hear! Hear! Hear!" Then the shaman says: "Grandmothers, pull up your legs, our children will come out into the open air". This phrase is repeated for three to four times. Then all the people stroll in the open air, have a rest and drink water, 
as the chum has been packed full of people and hot because of body heat and fire. Everyone exclaims: "Hear! Hear! Hear!"

\section{Episode 11}

After all the deities which are dependent on him have gathered, the shaman introduces everyone by name - both earthly deities and those living beyond seven permafrosts. The shaman begins to predict the fortune and future events to the person in whose honor (or for whom) he performs the shamanistic ritual (as a rule, in honor of the master of the chum). The master of the chum asks: "How will I live, what my life will be like, what will be my trade?" In other words, he begs the great deities, the Sky, the earthly deities, the underground $\mathrm{Nga}$ for happiness. He begs each deity, each Nga for happiness and success.

The deities-spirits which are dependent on the shaman will talk to each other, then the shaman will say what is right and what is wrong. He plays the drum, sings (see Photo 2.), his assistant also singing: "We have seen nothing evil for the dwellers of this chum. Your trade will be successful". As a rule, a man wishes a good trade and well-being to his family.

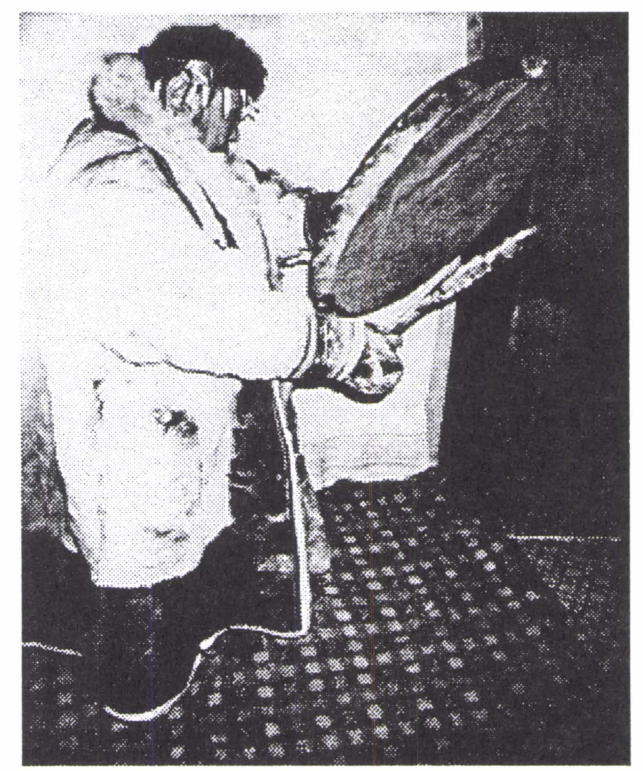

\section{Photo 2.}

These episodes can be followed by many more other episodes. Having completed his predictions for the master of the chum, the deities will recommend sacrifices: e.g. reindeer of certain colour must be sacrificed to the heaven. Sometimes reindeer will be sacrificed to earthly deities. Sacrificial reindeer must be a reindeer-bull. "Hear! Hear! Hear!" exclaim all those present. 
Then the shaman begins to predict the future to other spectators. Losses and misfortune can await some of them, in which case he will not mention the names, he will just give a hint. If the man guesses, he will ask the shaman a question: "Tell me about my future, I didn't quite get what the deities said". The shaman will heat the drum again and ask the deities again. The shaman stops, falls silent, he can't find words, he will only say: "They didn't say a word". The man will lapse into silence, while the shaman will predict the future to all those present. He predicted happiness to all with the exception of one man.

Afterwards the shaman will say: "Yalyanggora (Sunny Male) is waking up". $\mathrm{He}$ will see all the deities off, he will ask some of them to stay, he will say: "Some of you will stay to keep me company". At first he will send off heavenly deities, then earthly ones, some of them will stay to keep him company, he will send off all underground deities - not a single one of the latter will keep him company.

\section{Conclusion of the ritual}

The shaman throws the drum into the sacred corner of the chum, and a table is placed across the sacred corner, all food and drinks are placed on it. The people living in the chum have breakfast, the dwellers of neighbouring chums go home, as well as the dwellers of adjacent nomad camps. After breakfast the dwellers of the chum in which the shamanistic ritual had been performed go to bed. Waking up later during the day, they begin a ritual of offering sacrifice. The heads of the sacrificial animals will be sanctified by sable suet incense. They will sacrifice a reindeer, boil its meat, place vodka (there must be a little bit of vodka) and have tea. This is how a shamanistic ritual for predicting future events looks like in reconstruction.

\section{References:}

Lar, Leonid. Bogi i shamanï nentsev Yamala. Narodï Severo-Zapadnoy Sibiri (sbornik), vyp. 2. Tomsk: Izdatel'stvo Tomskogo universiteta. 161-177.

Lehtisalo, Toivo 1924. Entwurf einer Mythologie der Juraksamojeden. Helsinki: Société Finno-Ougrienne.

Khomich, Lyudmila 1981. Shamanï u nentsev. Problemï obshchestvennogo soznaniya aborigenov Sibiri. Leningrad: Nauka. 5-41.

Vinokurova, Ul'yana 1997. Pravo i shamanizm. Folks law and legal pluralism: Societies in transformation, Commission on Folks law and legal pluralism, $\mathrm{XI}$ international congress hosted by the Institute of Ethnology and Anthropology of the Russian Academy of Sciences, Moscow 18.-22. August 1997. Moscow: RAN. 108-109. 